\title{
Marko Aho
}

\section{Tähden koko kuva}

\section{Skaalan ääripäät}

Kun puhumme huomattavista nykyisistä ja edesmenneistä muusikoista, laulajista, säveltäjistä ja muista populaarimusiikin tekijöiden siniverisistä, ripustamme heihin usein sellaisia heidän statustansa kuvaavia nimilappuja kuin esimerkiksi "tähti", "ikoni”, "artisti", "viihdetaiteilija", ja "legenda". Voimme helposti sisällyttää näitä määreitä koko joukon myös peräkkäin. Miksi milloinkin määrittelemme kunkin populaarimusiikin edushahmon on pitkälti makuasia, mutta samalla kuitenkin tiedostamme, että jokainen pop-laulajakaan ei ole tähti, ja myös että jokainen iskelmätaivaan tähtikään ei loista yhtä kirkkaasti ja yhtä pitkään: on "tähtiä" ja "tähdenlentoja". Tähteydessä on pelkistetyimmillään kyse julkisesta olemassaolosta. Voimme ajatella julkisen eksistenssin kannalta kaksi tyystin erilaista tapausta: yhteen äärilaitaan henkilön, joka ei esiinny julkisuudessa millään tavalla; jatkumon toiseen päähän taas kotimaisissa puitteissammekin esiintyvän, mutta suuremmassa maailmassa vielä yleisemmän, jotensakin virtuaaliselta vaikuttavan mediahahmon, spektaakkelin, jonka olemassaoloa tvruudun ulkopuolella on vaikea spontaanisti kuvitella. Ymmärrämme kuitenkin että tämänkin hahmon taustalta on löydyttävä oikea ihminen - myös Michael Jacksonin täytyy syödä ja nukkua. Samoin, kun näemme vaikkapa samaisen amerikkalaisen megatähden miljoonan dollarin erikoistehosteilla ryyditetyllä videollaan, on helppo unohtaa, että myös hänenkin täytyy harjoitella fyysisesti: avata ääntä ja opetella tanssiaskeleet. Nämä asiat eivät kuitenkaan tapahdu julkisesti, vaan yksityisesti. Kuuluisuuden yksityselämän mukana palaamme tavallaan takaisin täyden kierroksen takaisin jatkumon alkupäähän, yksityishenkilöön.

Tässä artikkelissa käsittelen tähteyteen liittyviä ulottuvuuksia formaalilla mallilla, jossa olen suhteuttanut toisiinsa neljä käsitettä: "yksityishenkilö", "artisti", "kuuluisuus" ja "legenda". En pyri hahmotelmassani mihinkään normatiiviseen käsitemäärittelyyn, ainoastaan mallini sisäiseen: tähteyden komponentteja kuvaavat nimilaput eivät sinänsä ole tärkeitä, vaikka ovatkin toivoakseni suurin piirtein osuvia. Artikkelini on löyhästi jatkoa kahdessa edellisessä Etnomusikologian vuosikirjassa julkaisemilleni artikkeleille (Aho 1999; 2000), joissa olen käsitellyt Suomi-iskelmän ydinhahmojen olemusta narratiivisuuden ja kielenkäytön näkökulmista.

On ehkä hyvä kertoa, kuinka sain impulssin käsillä olevan formaalin mallin synnyttämiseen: erään kovan luokan iskelmäfanin tiedettä popularisoivasta artikkelistani anta- 
man palautteen sanoma oli, että etsiessäni suosion salaisuuksia olin eksynyt täysin ulkopuolelle oleellisesta keskittyessäni soivan musiikin sijaan viihdetaiteilijoita koskevaan puheeseen. En edes pyrkinyt tuomaan, tekstejä tutkittuani ja menneitäkin tongittuani, julki "totuutta" joistakin ammoisista tapahtumista. Ongelmakohtia tähdistä ja legendoista puhuttaessa tuntuivat olevan ensinnäkin historiallisen totuuden ja kertomusten suhde, sekä toiseksi musiikin ja ulkomusiikillisen aineksen suhde. Kun puhutaan massakulttuurin tuottamista tähdistä, jotka välittyvät yleisölle medioitten kautta, sekoittuu fakta ja fiktio, ruumiillisuus ja imago. Mikä tähdissä kiehtoo? Joillekuille se on "se ääni”, toisille "karisma". Näistä ominaisuuksista voidaan fyysisessä mielessä päästä nauttimaan äänitteitä kuuntelemalla ja konserteissa käymällä, televisiota katsomalla ja radiota kuuntelemalla. Kuitenkaan korvin kuultava musiikki ei ole ainoa tapa millä he keskuudessamme vaikuttavat. Heistä puhutaan, heistä luetaan lehtijuttuja, joistakuista jo kuolleista tehdään elokuvia - eikä musiikki aina ole läsnä silloin kun he ovat läsnä. Loppujen lopuksi on vaikea sanoa, miksi viehätymme populaarikulttuurin edushahmoista. Mikä merkitys on itse musiikilla, mikä kaikella sillä mikä jää musiikin ulkopuolelle? Ovatko ne itse asiassa edes erotettavissa toisistaan? Epäilemättä ihailijoidensa mielissä eivät. Idolin analysoiminen voi olla ihailijan mielestä jopa vastenmielistä.

\section{Tähden ja yleisön suhteesta kirjoitettua}

Tähteys on keskeinen määre kun tarkastellaan kulttuuriteollisuuden edushahmoja suosion näkökulmasta. Tähti on massakulttuurin markkinoinnin standardiyksikkö ja massakulttuurin kaupallisen luonteen vuoksi myös yleensä sen keskeisimpiä muuttujia. Tähteys on monitahoinen ilmiö sekä vaikea ja ongelmallinen tutkimuskohde, eikä se ole saanut osakseen sitä akateemista kiinnostusta minkä se ansaitsisi (mm. Shuker 1994, 111). Kirjoitukset tapaavat keskittyä yksittäisiin hahmoihin, yleensä kirjoittajan omiin suosikkeihin, ja siksi ne helposti paremminkin ovat vain lisää kohteitaan myytistäviä ja näiden erinomaisuutta todistelevia kuin tähtimyyttiä purkavia. Tähteyden olemusta on käsitelty aikaisemmin tieteellisesti enemmän elokuvataiteen kuin populaarimusiikin saralla, mutta yhtymäkohtia näiden kahden populaarikulttuurin siiven tähtien välillä on enemmän kuin eroja, ja usein yksittäisten tähtien kohdalla nämä taiteenalat myöskin sekoittuvat.

Tähteydestä puhuttaessa on tapana viitata sen "välittyneeseen" luonteeseen (esim. Thwaites \& al. 1994, 136-137; Grossberg \& al. 1998, 14-15), siihen että nämä aivan oikeasti olemassa olevat ihmiset tulevat yleisön luo vain median kautta, ei suoraan. Tietysti tällöin ajatellaan oletusarvoisesti amerikkalaisia supertähtiä, ei kotoisia rock"tähtiämme" joihin kadulla törmääminen ei ainakaan kotikaupungissani paljon ketään hetkauta. Periaatteen tasolla asia kuitenkin eittämättä on kuten Dyer kirjoittaa: 
"- - ajatellessamme tähtiä olemme tekemisissä näiden merkityksenannon, emme oikeiden ihmisten kanssa. Se että he ovat myös oikeita ihmisiä on tärkeä osa sitä kuinka he tuottavat merkityksiä, mutta me emme koskaan voi tuntea heitä todellisina ihmisinä, vaan ainoastaan sellaisina kuin he välittyvät median teksteistä." (Dyer 1986, 2)

Christine Gledhill (1991, 214-217) on elokuvatähtien kohdalla puhunut erityisestä tähtirakenteesta (star structure), joka koostuu 1) ihmisestä yksityishenkilönä, "kiteytymättömien ja muuntuvien ruumiillisten ominaisuuksien, vaistojen, psyykkisten impulssien ja kokemuksien kenttänä", 2) hänen "kuvitteellisten ja stereotyyppisten konventioiden määrittämistä" elokuvarooleistaan, 3) edelliset tasot yhdistävästä tähtipersoonasta, joka "muokkaa yksityiselämän julkiseen ja merkitykselliseen muotoon", sekä 4) kaikki edelliset 3 tasoa kattavasta tähtikuvasta (star image), eli kaikesta siitä, mitä tähdestä julkisuudessa tiedetään. Mäkelä jatkaa listaa vielä tähteyden, jonka Mäkelä määrittelee Dyeriä $(1986,39)$ lainaten mielikuvaksi tavasta, jolla tähdet elävät. Ellis $(1985,91)$ taas määrittelee tähden siten, että hän on jonkin tietyn median puitteissa toimiva esiintyjä, jonka hahmo välittyy myös muihin medioihin, joista palautuu edelleen vaikuttamaan tähden tuleviin esityksiin. Ellis (ibid., 92) kertoo kuinka elokuvan alkuaikoina näyttelijät olivat aivan toisarvoisia markkinoinnissa, ja vasta kun huomattiin yleisön viehättyvän joihinkin näyttelijöihin, alettiin heitä korostaa. Tuloksena oli mm. näyttelijöiden palkkioiden räjähtäminen taivaisiin. Tähdestä tuli osin sattumalta kaupallisen elokuvan oleellisin markkinointikeino - asiantila, jonka otamme nykyään itsestäänselvyytenä. Kun näyttelijät olivat aluksi julkisuudessa vain työnsä ja ammattinsa kautta, tähteyden syntymisen myötä uudeksi puheenaiheeksi nousi näyttelijän olemassaolo myös työn ulkopuolella, "yksityiselämässä" (deCordova 1991, 26).

On esitetty, että elokuvatähteyden toissijaiset julkisuusmuodot, kuten lehtihaastattelut valokuvineen, tuottavat omalla epätäydellisyydellään eräänlaisen "kutsun" katsomaan elokuvia: elokuva tarjoaa ikään kuin mahdollisuuden kokea tähti "kokonaisena", ei vain pysähtyneinä kuvina tai sanomisina. Arkiajattelussa vallitsee vaistomainen käsitys, että nämä toissijaiset julkisuusmuodot toisivat esille "oikean henkilön" roolien takaa, tähden sellaisena kuin hän todellisuudessa yksityishenkilönä on. Näiden julkisuusmuotojen totuusarvo tässä mielessä on kuitenkin jatkuvasti heikentynyt tietoisen promootion noustessa niiden määrääväksi periaatteeksi. Itse asiassa on syntynyt uudenlaisia tähtiä, joiden performatiivisuus jokaisella julkisuuden kanavalla on muuttunut täysin peittelemättömäksi: näiden tähtien viehätys perustuukin nimenomaan heidän kyvyssä muuttaa "aktuaalinen virtuaaliseksi" ja "virtuaalinen aktuaaliseksi". (Lury 1993, 69-71.)

Dyer (1986, 48-49) viittaa tahollaan periamerikkalaiseen demokraattiseen menestyksen myyttiin, antiteesiin stereotyyppiselle degeneroituneelle vanhan mantereen luokkayhteiskuntien harvainvallalle. Amerikkalaisessa mytologiassa jokainen on oman onnensa seppä, ja amerikkalaisessa yhteiskunnassa jokaisella on yhtälaiset lähtökohdat menestymiseen riippumatta sosiaalisista lähtökohdista. Samantapainen dynamiikka 
tavallisuuden ja erikoisuuden välillä on taatusti löydettävissä myös muualta kuin Amerikasta - tarvitsee vain vilkaista kotoisia tangokuninkaallisia, entisiä myyjättäriä ja rakennusmestareita tämän huomatakseen. Dyer (ibid., 7) viittaa Francesco Alberonin ajatukseen siitä, että tähdissä kyseessä on joukko jonka institutionaalinen valta on mitätön, mutta joka silti kiinnostaa. Tähdet ovat merkillisiä siinä, että vaikka ovat etuoikeutettuja, eivät herätä kateutta, koska kuka tahansa voi nousta sellaiseksi, ja toiseksi eivät omaa todellista polittista valtaa. Dyer luettelee tähteyden edellytyksiä: 1) tavallisuus leimaa tähteä 2) tähdeksi pääsee kuitenkin lahjojen ja erityisyyden kautta 3) hyvä onni, joka voi potkaista ketä tahansa liittyy tähdeksi tulemiseen elimellisesti 4) kova työ ja ammattimaisuus ovat välttämättömiä edellytyksiä. (ks. Myös Ellis 1985, 94-95)

\section{Legendan uraputki}

Annan nyt esimerkkikuvailut neljästä erilaisesta musiikin parissa toimivasta hahmosta. Kaksi ensimmäistä heistä on vailla nimeä, kaksi jälkimmäistä ovat Elvis Presley eri vuosina.

1) Kotonaan musisoiva harrastelija: hänen nimellään ei ole merkitystä, koska sinä lukija et kuitenkaan häntä tunne - tai ehkäpä toisaalta tunnet montakin. Hän soittaa vain harvoin muiden kuullen. Esiintymisestä ei näissä yhteyksissä voi puhua. Muusikkoutta ei yhdistetä häneen, harva tietää hänen osaavan soittaa, eikä hänen soittotaidossaan ehkä paljon tietämistä olekaan.

2) Rivimuusikon nimeä ei näy mainosjulisteissa. Hän on silti ehkä jopa hyvin palkattu ammattilainen joka hallitsee instrumenttinsa taitavasti. Hän jää silti yleisölle anonyymiksi, vain yhdeksi rivissä.

3) Comebackia tavoitteleva Elvis Presley saapumassa studioon Memphisissä 13. tammikuuta 1969. Äänityssessio alkaa kappaleella "Long Black Limousine". "Me olimme kyllä toki innoissamme Elviksestä", kertoo sessioon osallistunut trumpetisti Wayne Jackson, "mutta eihän se ollut mitään Neil Diamondiin verrattavaa" (Guralnick 1999, 329).

4) Elvis vuosituhannen vaihteen Amerikassa. Elvis voidaan tavata kaikkialla: "Putkahtamassa esille lauluista, elokuvista, tv-ohjelmista, mainoksista, sanomalehdistä, aikakauslehdistä, sarjakuvista, t-paidoista, runoista, näytelmistä, novelleista, romaaneista, lastenkirjoista, akateemisista julkaisuista, yliopistokursseista, taidenäyttelyistä, 
tietokoneohjelmista, keittokirjoista, poliittisista kampanjoista, postimerkeistä ja lukemattomista muista kulttuurin maastokohdista jotka uhmaavat arkijärjen käsitystä siitä kuinka kuolleitten tähtien tulisi käyttäytyä" (Rodman 1996, 1).

Mistä näissä esimerkeissä on kyse? Käsittelen seuraavaksi jokaisen esimerkin edustamaa tilannetta yksi kerrallaan. Ensinäkemältä ne vaikuttavat narraatiolta, vaiheilta tähden uralla, tai esimerkeiltä erilaisista muusikoista. Niitä voidaan kuitenkin myös ajatella esimerkkeinä erilaisista muusikkouteen liittyvistä aspekteista. Tässä artikkelissa hahmotellun mallin tarkoitus onkin juuri niiden eri osien hahmottaminen, mitä "tähdeksi” kutsuttava kokonaisuus pitää sisällään. Monet määreet sekoittuvat keskenään silloin kun puhutaan populaarimusiikin edushahmoista, ja näillä kaikilla on omat vivahteensa jotka ilmentävät tähteyden tematiikan monitahoisuutta. Keskeisiksi muuttujiksi malliin on otettu todellisuuden ja todellisuuden esityksen, samastumisen ja ihailun sekä tähden läheisyyden ja etäisyyden oppositiot.

1. Ensimmäisessä tilanteessa on kyseessä tavallinen kansalainen johon media ei kohdista mielenkiintoa: julkisuuden perspektiivistä kyseessä on "yksityishenkilö", ja median vastaanottajien perspektiivistä "yksityishenkilöllä" ei ole olemassa julkista eksistenssiä. Jokainen ns. julkisuuden henkilökin on jossain vaiheessa elämäänsä ollut tällainen, poisluettuna kuuluisuuksien lapset sekä sellaiset kuviteltavissa olevat kuriositeettitapaukset, joiden kohdalla syntymän hetkellä tapahtuu kohtalonoikusta jotain sellaista, jonka ansiosta heidän nimensä nousee jo tuolloin kansakunnan huulille.

Myös supertähdellä on kaikesta yleisön mielenkiinnosta huolimatta yksityiselämänsä, olkoon se sitten kuinka kapea saareke tahansa. Aspektina "yksityishenkilö" on se osa tähteä, joka ei ole olemassa julkisesti. Yleisölle voi toki välittyä jonkinlainen kuva tähden yksityiselämästä, mutta se on vain representaatio tähden oikeasta elämän privaattipuolesta. "Yksityishenkilönä" tähti lähestyy ominaisuuksiltaan yleisöä: tähdelläkin on tavanomaiset fyysiset perustarpeet, joiden tyydyttämisessä ei voi elämäntavasta riippumatta olla kovinkaan suurta variaatiota. Monen tähden kohdalla yksityiselämä pitää sisällään myös hyvin paljon kulttuurisesti samankaltaista sisältöä kuin yleisön arki: siinä kuin keskimäärin, myös tähtien avioliitot menevät pieleen, ja joskus myös tähti tulee ottaneeksi yhden drinkin liikaa. Voidaankin sanoa, että juuri "yksityishenkilönä" tähti on tavallisimmillaan. Tietysti tähtien yksityiselämien puolelta on löydettävissä hyvin monipuolista äärikäyttäytymistäkin, mutta niinhän on löydettävissä myös ns. tavallisten ihmisten elämästä

Yleisölle välittyvä kuva tähden yksityiselämästä on vain todellisuuden esitys. Eräs arvostelija kirjoitti seuraavasti elokuvasta In Bed With Madonna, jossa yritetään välittää kuvaa Madonnan yksityiselämästä: 


\begin{abstract}
"Huolimatta Madonnan uran eri vaiheiden kronologisesta järjestyksestä, hän on ensiksi filmitähti ja vasta toiseksi pop-tähti. Sillä ei ole merkitystä onko hän lavalla vai ei - vain sillä on merkitystä, että hän on kameran edessä, ja siten esiintymässä. 'Miksi hän haluaisi sanoa mitään kameran ollessa pois päältä? Eihän hän halua elää kameran ollessa pois päältä', mumisee Warren Beatty osuen naulan kantaan. Ette te enkä minä ikinä tule näkemään Madonnaa yksityisoloissa." (Kermode 1991, 102, Luryn 1993, 71 mukaan, käännös kirjoittajan)
\end{abstract}

Siinä missä yleisölle välittyvä kuva tähden yksityiselämästä on vain todellisuuden esitys, on kaikki "yksityishenkilön" alaan kuuluva tähdelle itselleen ohikiitävää fyysistä todellisuutta; myös historiallinen totuus kuuluu tuohon maailmaan. Historiallista totuutta ei voi vangita: voidaan ainoastaan esittää historiallisen totuuden representaatioita. Historiallinen totuus on kuitenkin siitä huolimatta olemassa: jotain todellakin tapahtui tietyssä pisteessä aikaa ja avaruutta. Niinpä historiallinen totuus, ja samalla myös "yksityishenkilö" sellaisena kuin se on tässä määritelty, säilyy senkin jälkeen kun fyysisen henkilön maallinen vaellus on päättynyt.

2. Seuraavassa momentissa "yksityishenkilö" on kehittynyt statukseltaan musiikintekijäksi: soittajaksi, laulajaksi, säveltäjäksi, sanoittajaksi tai sovittajaksi. "Artistin" myötä julkinen musiikin tekeminen alkaa. Henkilö on ylittänyt rajan yleisöstä tekijään, siirtynyt inklusiivisesta eksklusiiviseen joukkoon. Vielä hän ei ehkä persoonalleen saa osakseen huomiota, mutta musiikin kautta julkinen elämä on yhtä kaikki nyt alkanut, oli musiikillinen toiminta sitten elävän yleisön edessä esiintymistä, vain äänitallenteiden välityksellä tapahtuvaa tai vaikkapa epäsuorasti muille julkisesti esiintyville musisoijille musiikin tekemistä.

Tähteyteen liittyvänä aspektina "artisti” sisältää tähden julkisen musiikillisen panoksen, niiden kykyjen julkisen manifestaation joihin tämän tähteys ideaalisesti perustuu. Kun tähti "yksityishenkilönä" on ominaisuuksiltaan eriytymätön, on tämä "artistina" varustettu erityisillä kyvyillä eli musiikillisella lahjakkuudella. Edelleen "artisti" kuten "yksityishenkilökin" on fyysistä todellisuutta: musiikki kuullaan, teatraalinen komponentti nähdään. Mekaanisen musiikintallennuksen aikakaudella "artisti" elää myös äänitallenteissa, eikä näin ollen ole tallennetuksi tultuaan riippuvainen tähtipersoonan maallisen tomumajan tilasta ${ }^{1}$.

3. Joistakin musiikintekijöistä tulee tähtiä. Tällöin musiikintekijä muuttuu julkisuudessa anonyymistä persoonaksi. Muusikon persoonaan ei kohdistu mielenkiintoa, tähden persoonaan kohdistuu: media alkaa tarjota tätä tietoa. Lisäksi markkinointi lisääntyy, ja tässäkin yhteydessä tähti on mukana myös persoonallaan, ei pelkästään musiikillaan. Syntyy "kuuluisuus", jonka sisältö on ulkomusiikillista ainesta; markkinoin-

\footnotetext{
1 Jarkko Laineen lyhyt runo menee suurin piirtein tähän tapaan: "Ei Jimi Hendrix ole kuollut, vasta eilenhän kuulin häntä radiossa".
} 
tia, promootiota, tähden kuvalla varustettuja virallisia t-paitoja, median raportointia tähden edesottamuksista. Periaatteessa voidaan ajatella ero sellaisen ulkomusiikillisen aineksen välille, jonka on tuottanut tähtipersoona itse sekä tämän kaupalliset taustavoimat, sekä toisaalta media spontaanisti ilman edellisten voimien suoraa panostusta. Kyseessä on kummassakin tapauksessa kuitenkin täydellisessä symbioosissa elävien kulttuuriteollisuuden eri haarojen primäärituotantoa, jonka suunta on teollisuudelta kuluttajille. Tällä tavoin ymmärrettynä myös esimerkiksi levykritiikki on paljon lähempänä promootiota kuin varsinaista vastaanottajien tulkintaa kulttuurintuotteista.

Joissakin tapauksessa musiikkielämän "kuuluisuus" voi syntyä ilman mitään siihen liittyvää musiikillista panosta, "artistia". Voidaan ajatella esimerkiksi tilanne, jossa laaja ns. media-hype ${ }^{2}$ edeltää merkittävän levytyssopimuksen tehneen nuoriso-orkesterin tai -laulajan debyyttilevyä. Äärimmäisessä tapauksessa mitään levyä ei ikinä tulekaan - eikä koko artistiakaan ole olemassa.

Aspektina "kuuluisuus" pitää sisällään ensinnäkin representaation tähdestä "yksityishenkilönä", olematta kuitenkaan aidosti tätä: kyseessä on, kuten todettua, todellisuuden esitys, ei totuus. Tämä representaatio tähden tavallisista ominaisuuksista toimii sinä tähteyden komponenttina, johon suurella yleisöllä on mahdollisuus samastua. Toisaalta "kuuluisuuden" sisältöön kuuluu myös "kuuluisuuden" itsensä raportointi urheiluautot, palatsinomaiset kodit, rajattomasti seksiä viehättävien partnerien kanssa - johon yleisö tuskin samastuu. "Kuuluisuuteen" kohdistuva mielenkiinto kohdistuu nimenomaan "juuri nyt" tähdelle tapahtuvaan, ja median raportointi keskittyykin tyypillisesti tähden viimeaikaisiin kuulumisiin. Lisäksi tähteen luodaan myös retrospektiivisiä katsauksia, ja näissä, riippumatta siitä onko tähti itse mukana kommentoimassa vai ei, on tämän olemassaolo joka tapauksessa otettava huomioon: karkeana esimerkkinä epätotuudenmukainen uutisointi voi saattaa uutisoijat oikeuteen, mutta lievimmilläänkin tietoisuus tähden fyysisestä olemassaolosta vaikuttaa totuuden muuntelua rajoittavasti. Historiallinen totuus on liian lähellä jotta se voisi päästää kokonaan otteestaan.

4. Viimeisenä vaiheena narraatiossa toteutuu "legenda", jonka myötä on edetty ääripäähän alkupisteestä, "yksityishenkilöstä". "Legenda" kehittyy karkeasti sanottuna tähdestä, jonka pohjana ollut fyysinen henkilö ei enää toimi tehtävässään viihdeteollisuuden palveluksessa eikä tuota tuota "kuuluisuuden" substanssia, mutta joka silti ei katoa julkisuudesta: uutta musiikkia ei enää tule markkinoille, uusia avioliittoja ei enää synny, mutta hahmon ympärille syntyy edelleen yhä uusia ja uusia kulttuurintuotteita. Näiden kultturintuotteiden muodossa hahmo nousee elämää suuremmaksi ja kuolemattomaksi, mitä määreitä näistä hahmoista myös käytetään. Tähdet syttyvät ja sammuvat, ja vain jotkut jäävät hahmoina elämään, vetämään puoleensa myös aika-

2 Media-hype tarkoittaa suurin piirtein laajamittaista, kulovalkean tavoin leviävää kulttuurituotteen käsittelyä mediassa. 
laisten jälkeistä mieleenkiintoa varsinaisen päivänpolttavuuden heidän kohdallaan lopullisesti rauettua. Toki kuolemankin jälkeen jäävät levyt, elokuvat, kaikki sellainen joka tuottaa muistuman heidän fyysisestä olemassaolostaan - mutta tämä tarkoittaa vain sitä, että myös "artistin" elämä jatkuu niin kauan kuin yksikin äänite on tallella. Paradoksaalista kylläkin juuri kuoleman jälkeen monen artistin kohdalla äänitemyynti ja markkinointi saavuttaa koko uran huipun, ja vielä pitkään kuoleman jälkeen markkinoille ilmestyy kokoelmalevyjä, uusintajulkaisuja ja aikaisemmin julkaisematta jääneitä äänityksiä, joita promotoidaan suurin piirtein samalla tavoin kuin artistin elinaikanakin.

"Artisti" ja "yksityishenkilö" ovat fyysisyyttä, "legenda" metafyysisyyttä. "Legenda" tarkoittaa sanakirjamääritelmän mukaan tarunhohtoista: legendaarius elää nimenomaan kertomuksissa. On olemassa legendaarisia muusikoita, joiden musiikista kukaan nykyihminen ei ole kuullut nuottiakaan. Niinpä 1900-luvun vaihteessa New Orleansissa vaikuttaneen "maailman ensimmäisen jazz-trumpetistin" Buddy Boldenin kerrotaan mittailleen kotikaupunkinsa katuja neljä viisi naista kainalossaan, ja hänen trumpetinsa äänen taas on kerrottu kuuluneen tyynellä säällä neljäntoista mailin päähän (Carr et al. 1996, 65). Bolden ei koskaan levyttänyt, joten tästä majesteetillisesta saundista ei ole jäljellä muuta kuin kertomukset. Esimerkki havainnollistaa, kuinka kertomukset joiden varassa "legenda" elää, eivät ole kiinteässä suhteessa historialliseen totuuteen - ne joko ovat totta, tai sitten eivät, ja legendaariuden kannalta tämä on yhdentekevää. Voidaan tietysti ajatella, että historiallinen totuuskin on olemassa: tarkalleen mitä se sisältää, emme kuitenkaan saa tietää. Historiallinen totuus jää pakosta pelkästään suhteelliseksi, sulkeistetuksi "historialliseksi totuudeksi". Heti kun historiallista totuutta yritetään välittää yleisölle, kääntyy se pelkäksi representaatioksi historiallisesta totuudesta, ja muuttuu "kuuluisuuden" raaka-aineeksi. "Yksityishenkilö" pakenee lopulta kaikkia lähestymisyrityksiä.

Legendaksi ei voi nousta luontevasti vielä tähtipersoonan aktiiviuran aikana: historiallinen ja fyysinen todellisuus, elämä, on liian lähellä jotta hahmo voisi esteettä nousta elämää suurempiin mittasuhteisiin. Jollekulle viihdetaiteilijalle voidaan tietysti jonkinlaista kuolemattomuutta uumoilla jo uran ollessa käynnissä. Aktiiviuran aikana kuitenkin nimenomaan tehdään niitä asioita, joiden päälle "legendasta" kertovat tarinat myöhemmin enemmän tai vähemmän löyhästi rakentuvat. "Legenda" on potentiaalisesti vielä kauempana historiallisesta totuudesta kuin "kuuluisuus", koska yhä harvempi ajan kuluessa enää edes väittää tietävänsä historiallista totuutta, ja tähden fyysisen kuoleman jälkeen historiallinen totuus jää vuosi vuodelta yhä kauemmaksi antaen tilaa osittain fiktiivisille kertomuksille. Samoin kuin "kuuluisuuteen", myös "legendaan" kuuluu "yksityishenkilöä" representoiva aspekti, johon tavalliset ihmiset voivat samastua. Toisaalta "legendaan" kuuluu myös äärimmäinen liioittelu, johon kukaan ei suoraan voi samastua, ainoastaan kiertoteitse "legendan" tavallisuuden komponentin kautta. 
Siitä lähtien kun tähti on iskostunut yleisön tietoisuuteen, alkaa syntyä kulttuurintuotteita, joita tähti kaupallisine taustavoimineen tai näihin kytkoksissä oleva ja näiltä valmista sisältöä käyttöönsä saava kulttuuriteollisuus eivät ole mukana tuottamassa. Nämä tahot ovat tarjonneet impulssin, kulttuuriset tekstit, jotka ovat lähteneet heidän käsistään maailman turuille: tämä projektio muuttuu reflektioksi, kun vastaanottajat tekevät niistä omat tulkintansa, ja tekevät näiden pohjalta taas uusia kulttuurintuotteita, reflektio-kulttuurintuotteita. Näitä kulttuurintuotteita tekevät sekä fanit, mutta myöskin media - vai pitäisikö sanoa fanit mediassa. Oleellista on se, että kyse on ensimmäisen asteen tuotteiden tulkintoihin perustuvasta toisen asteen tuotannosta. "Legendaksi" muuttuneen tähden julkinen elämä jatkuu lehtiartikkeleissa, elämänkertakirjoissa, tvdokumenteissa ja fan-clubien jäsenkirjeissä omia ratojaan.

Kaikki edellä selostetut tähteyden ulottuvuudet voidaan nyt yhdistää kolmiulotteiseksi kaavioksi, joka symboloi tähden kokonaisuutta osakomponentteineen. Kaavioon on sijoitettu komponenttien olemusta kuvaavien muuttujien lisäksi myös niihin liittyvä julkinen ainesosa - jota yksityishenkilöllä ei määritelmän mukaan kuitenkaan ole.

Kaavio 1. Tähti osineen

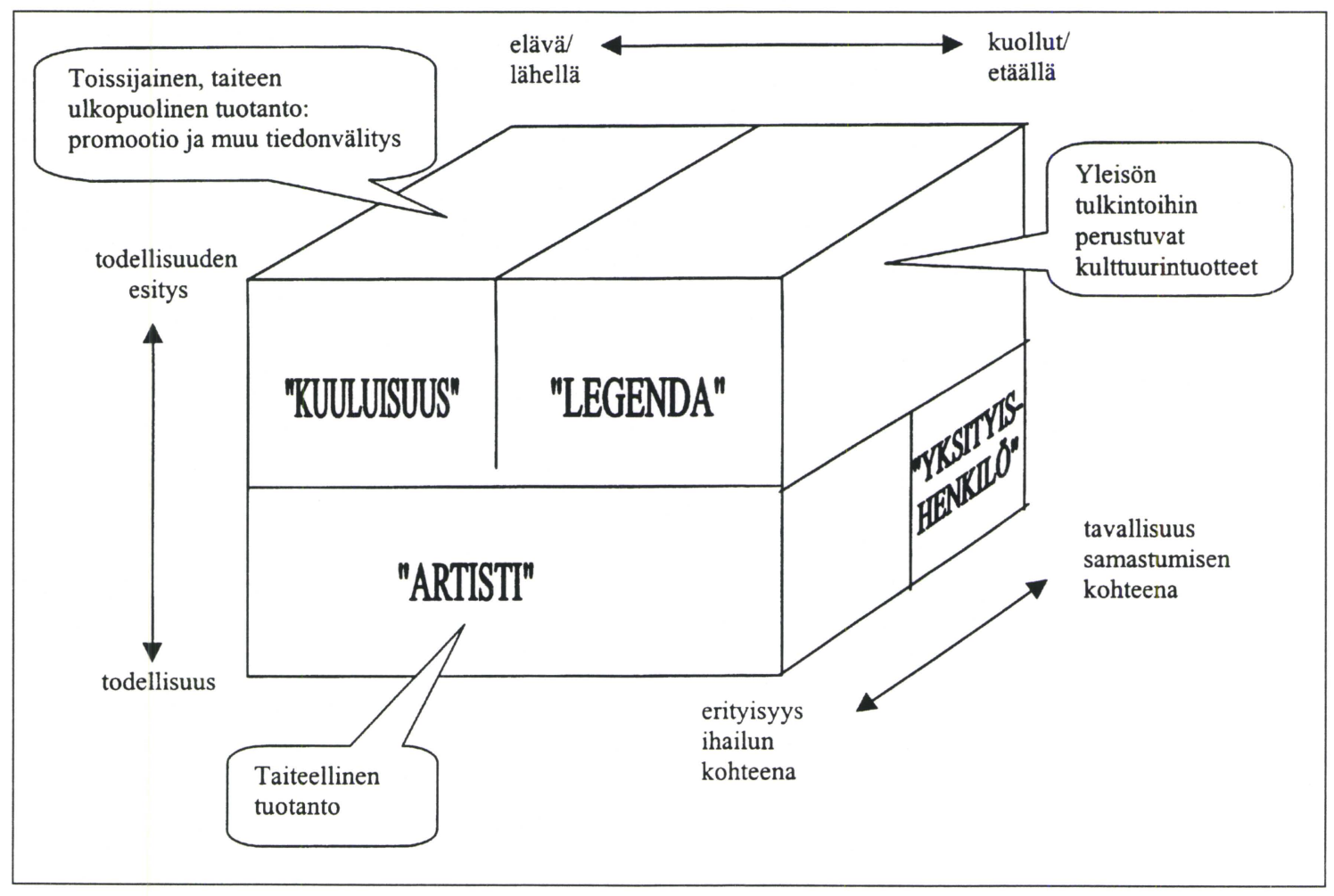


Yksittäisen ihailijan viehtymys pop-idoliinsa voi perustua teoriassa joko täysin tämän musiikilliseen panokseen liittyviin ominaisuuksiin, muuhun tähdestä välittyvään tietoon tai sitten molempiin, mikä lieneekin kaikkein luontevinta. Fyysinen yksilö tähden hahmon takana sekä musiikki ovat todellisuutta siinä missä tiedonvälitys on vain tehtyä keinotodellisuutta, todellisuuden representaatio, itsessään kyllä totta mutta vain virtuaalisesti. Kuuluisuus perustuu tähden projektioon, mutta tarunhohtoisuus syntyy vasta kun tämä projektio on vastaanotettu, tulkittu ja reflektoitu muillekin tiettäväksi. Tämä tapahtuu tyypillisesti tähden kuoleman jälkeen, kun tähden latteaan todellisuuteen aina jossain märin ankkuroitunut projektio ei häiritse ihailijoiden mielikuvituksellisten tulkintojen tuottamia todellisuuspakoisia reflektioita. Yhden reflektio on toiselle projektio, ja näin legenda-efekti vain kertautuu. On myös syytä erottaa toisistaan vielä ihailu ja samastuminen. Artisteja ihaillaan heidän harvinaislaatuisten kykyjensä vuoksi. Näihin kykyihin ei ihailija voi kuitenkaan samastua, koska hänellä itsellään niitä ei ole. Niinpä samastuminen tapahtuu siihen, mihin idolissa voidaan samastua: kaikkeen sellaiseen mitä tässä nähdään olevan yhteistä oman itsen kanssa. Tällaisia piirteitä voivat yleisimmillään olla vaikkapa sukupuoli, etnisyys tai kansallisuus.

\section{Kulttuurintuotteet}

Kuten todettua, emme kohtaa tähtiä ihmisinä, vaan median kautta välittyneinä representaatioina. Mitä kaikkea välitettävä aines pitää sisällään? Richard Dyer (1986, 6871) erittelee seuraavasti sitä mediatekstien runsautta, mistä elokuvatähden kuva (star image) muodostuu: 1) Promootio käsittää ne tekstit, jotka on tuotettu tähden imagon tietoiseen muokkaukseen/tuottamiseen. Siihen kuuluu ensinnäkin materiaali joka liittyy suoraan kyseiseen tähteen - lehdistötiedotteet, fan-club-julkaisut, julisteet, julkiset näyttäytymiset erilaisissa tilaisuuksissa joista media raportoi yleisölle, mainokset joissa tähti manostaa jotain; toiseksi materiaali joka mainostaa tähteä tietyssä filmissä - mainokset, trailerit yms. 2) Promootiolle läheistä on julkisuusmateriaali, joka teoreettisesti eroaa edellisestä siten että ei ole tietoista imagonrakennusta. Se pitää sisällään sen minkä "lehdistö saa selville" tai minkä "tähti paljastaa" haastattelussa. 3) Elokuvat itse voidaan tehdä pönkittämään jonkun näyttelijän imagoa. 4) Kritiikki on joko arvottavaa tai tulkitsevaa tähteen kohdistuvaa kirjoittelua. Kritiikki voi olla myös kuolemanjälkeistä, kuten muistokirjoituksissa. Tämän kategorian tekstejä löytyy filmiarvosteluina, kirjoina sekä tähdistä tehtyinä tv- tai radio-ohjelmina.

Mäkelä (1999, 14-15) on tehnyt edellisen jaottelun pohjalta paremmin musiikkibisnekseen soveltuvan tyypittelyn. Tähän kuuluu: 1) Musiikki eri muodoissaan, levyillä ja konserteissa jne., mutta myös tähdestä riippuen filmiroolit, haastattelut, omaelämäkerrat ja muut tähden "omat tekemiset"; 2) promootiomateriaali; 3) tiedotusvälinei- 
den kommentit tähdestä kritiikin, uutisten, kolumnien, sketsien, parodioiden yms. muodossa; 4) kulutus ja yleisö, pitäen sisällään yleisön luomat artefaktit, fanzinet ja kirjoittamat fanikirjeet.

Edelliset jaottelut siis ryhmittelevät tuotteet niiden lähteen mukaan, esim. Mäkelän jaottelussa seuraavaan tapaan: 1) lähteenä tähtipersoona itse; 2) lähteenä levy-yhtiö; 3) tiedotusvälineet ja 4) fanit. Itse olen päätynyt vielä typistetympään jaotteluun, jossa tuotteet jaetaan institutionaaliseen primaarituotantoon, projektio-kulttuurintuotteisiin (liite 1), jota luovat tähtipersoona, levy-yhtiö sekä näiden kanssa symbioosissa elävä media, ja reflektio-kulttuurintuotteisiin (liite 2), joita luovat edellisten tuotteiden vastaanottajat näistä tekemiensä tulkintojen pohjalta. Esimerkiksi elokuva jossa Frank Sinatra esiintyy, kuuluu edelliseen kategoriaan, mutta elokuva Frank Sinatrasta jälkimmäiseen. Ensimmäiseen kategoriaan kuuluvat mm. tähden medialle antamat ja mediassa julkistetut haastattelut, hänen julkaisemansa levytykset, tapaamiset onnellisten nuorisolehden arvonnassa pääpalkinnon voittaneiden ihailijoiden kanssa: lyhyesti sanottuna kaikki sellainen missä yhteydessä tähti toimii ammatissaan viihdeteollisuuden palveluksessa. Tällöin tuotettu aines on tuotettu tähden ja hänen taustavoimiensa toimesta taloudellisen voiton toivossa, sekä tähden kannalta myös taiteellisen itseilmaisun merkeissä. Reflektio-kulttuurintuotteet ovat edellisten tuotteiden tulkintoihin pohjautuvia kulttuurintuotteita, joiden sisältöön primäärituottajilla ei ole mahdollisuuksia vaikuttaa. Jako ei luonnollisestikaan ole käytännössä monien mediatuotteiden osalta täysin selväpiirteinen, mutta lienee täysin yksiselitteinen esimerkiksi ihailijoiden tekemien idoli-aiheisten taideteosten osalta. Artikkelin liitteinä on molemmista kategorioista kaaviot, joihin olen sijoittanut erilaisia kulttuurintuotteita. Toivon lukijan ymmärtävän, että täysin kattavien kaavioiden laatimisen yrittäminen olisi toivoton yritys. On huomionarvoista, että narratiivisuus tuntuisi olevan keskeinen feedbackkulttuurintuotteiden ominaisuus: kätevin tapa muistaa kuollutta tähteä on kerrata tämän elämänkaarta. Lopuksi vielä on syytä huomata, että kulttuurintuotteet ovat kytköksissä kulloinkin käytössä olevaan teknologiaan ja fyysisiin formaatteihin, joista jotkut jäävät pois käytöstä toisten syntyessä.

\section{Paluu Gracelandiin}

Havainnollistaakseni edellä esitettyä typologiaa käsittelen tässä muutamia nimikkeitä sellaisista kulttuurintuotteista joita on syntynyt Elvis Presleyn legendaarisen hahmon ympärille. Uransa aikana Elvis tuotti materiaalia niitä kaikkia mahdollisia teknologisia kanavia pitkin, joita 1950-luvun alusta 1970-luvun puoleenväliin saakka oli käytettävissä. Elvis oli jopa osallisena merkittävässä teknologisessa läpimurrossa, kun hänen konserttinsa Hawaijilla vuonna 1973 lähetettiin satelliitin välityksellä ympäri 
maailmaa; lähetys sai maailmanlaajuisesti 1,5 miljardia katselijaa (Guralnick 1999, 475). Elvis konsertoi yleisölle 50-luvun alusta aina vuoteen 1958 asepalvelukseen astumiseensa saakka, ja uudelleen laajemmassa mittakaavassa jälleen vuodesta 1968 aina kuolemaansa vuoteen 1977. (Guralnick 1999.) Armeijasta paluunsa ja vuoden 1968 välisenä aikana hän teki mittavan joukon elokuvia sekä näihin liittyneitä soundtrack-levytyksiä: kuningasajatuksena tässä järjestelyssä oli se, että nämä promotoivat toinen toisiaan. Kaiken kaikkiaan Elvis julkaisi pyörryttävän määrän levyjä, mm. loputtoman sortimentin kokoelmalevyjä sekä konserttitaltiointeja, joista viimeinen on luultavasti vieläkin julkaisematta. Elviksen promootio oli miltei yhtä lailla legendaarisen eversti Parkerin käsissä. Epäkonventionaalisten metodiensa avulla Parker onnistui ylläpitämään ällistyttävää mediamielenkiintoa Elvistä kohtaan myös niiden kahden asepalvelusvuoden ajan, jolloin Elvis henkilökohtaisesti oli median tavoittamattomissa (ibid.).

Elviksen kuoleman 1977 jälkeen Elvikseen liittyvä primäärituotanto on jatkunut huomattavalla volyymillä: uusintajulkaisu- sekä kokoelma-albumien virta on ollut koko ajan tasainen. Merkillisenä erikoisuutena, tavoitteenaan luoda illuusio autenttisesta Elvis-konsertista,

\footnotetext{
"Tuottajat editoivat ja yhdistelivät kokoelman Elviksen hienoimpia filmille ja videolle tallennettuja konserttiesityksiä, ja irrottivat ääniraidalta kaiken muun äänen paitsi Elviksen laulun. Elviksen kuvatallenne projisoidaan laajalle videokankaalle. Lavalla on 16-miehinen orkesteri sekä joukko alkuperäisten taltiointien aikaisen orkesterin jäseniä, jotka esiintyvät elävänä kuva- ja äänitaltioinnin kera. Kaikki konsertissa kuultava musiikki tuotetaan paikan päällä lukuunottamatta Elviksen ääntä. Kummallakin puolen Elviksen videokangasta on kankaat, joille projisoidaan toiminta lavalta. Ensimmäisestä laulusta lähtien konsertti on taikuutta. Olet oikeassa Elvis-konsertissa!" (Elvis - The Concert, käännös kirjoittajan)
}

Satoihin tuote-artikkeleihin yltävän Elvis Presley Enterprises -yhtiön kontrolloiman virallisen Elvis -memorabilian tuottaa joko Elvis Presley Enterprises -yhtiö itse tai tahot joille edellinen on myöntänyt tuotantolisenssin (Elvis.com the official website). Vuonna 2000 Elviksen perikunta ansaitsi lähes 240 miljoonaa markkaa muun muassa lisensseinä ja rojalteina; yli 100 miljoonaa tuli Elviksen kartanon Gracelandin pääsylipputuloista, loput memorabiliasta ${ }^{3}$. Mutta näiden Elviksen perikuntaan ja muihin Elviksen perintöön oikeuksia omaaviin tahoihin yhdistettävissä olevien tuotteiden on olemassa myös lukemattomia muita kulttuurintuotteita joissa Elvis on läsnä tavalla tai toisella. Näiden joukkoon lukeutuu eräs maailmanlaajuinen ilmiö: Elviksen imitointi.

Elvis-imitaattorit materialisoivat taiteessaan tulkintansa Elviksestä. Ohjelmanumeroita on olemassa aina suureellisista yökerhoshow-tyyppisistä aina eriskummallisiin hääjuhlaesityksiin, ja esiintyjiä löytyy kaikissa koissa, muodoissa ja sukupuolissa yhtä

3 Tv-maailma 15-16/2001. 
vaihtelevilla kyvyillä varustettuna. Täydellinen yhdennäköisyys tai äänellinen imitaatio on merkityksetöntä: vain muutama avainelementti vaaditaan riittävän mielleyhtymän luomiseksi, tyypillisesti nimenomaan 1970-luvun Elviksen habitukseen: pulisongit, koristeltu haalari, aurinkolasit - muuta ei tarvita. Yksilölliset motivaatiot Elviksen imitoimiseen varmaankin vaihtelevat, mutta pohjalla useimmilla imitaattoreilla lienee vahva ihailijasuhde Elvikseen.

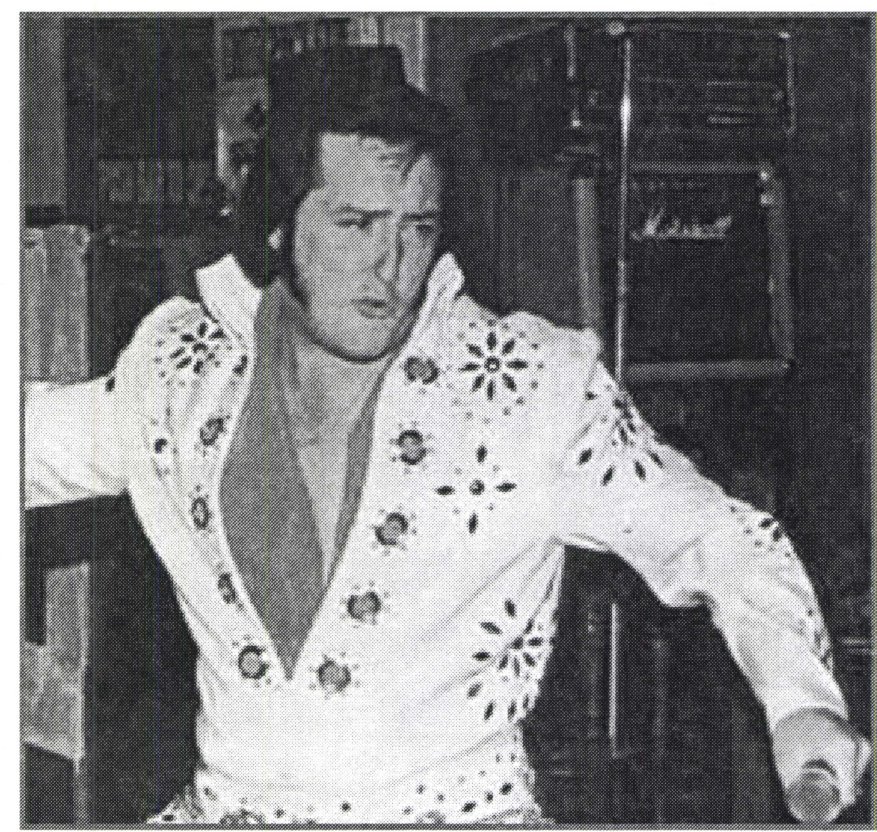

"Ihmiset kysyvät minulta aina, 'miksi et halua olla lavalla oma itsesi?' Elviksenä oleminen on minulle eräänlaista todellisuuspakoa. Pari tuntia viikossa voin olla sankarini - sankari, kuningas! Niin kuin suuri mies kerran sanoi, '...jos voin uneksia...", - Kim Bridges (Kim Bridges homepage, käännös kirjoittajan)

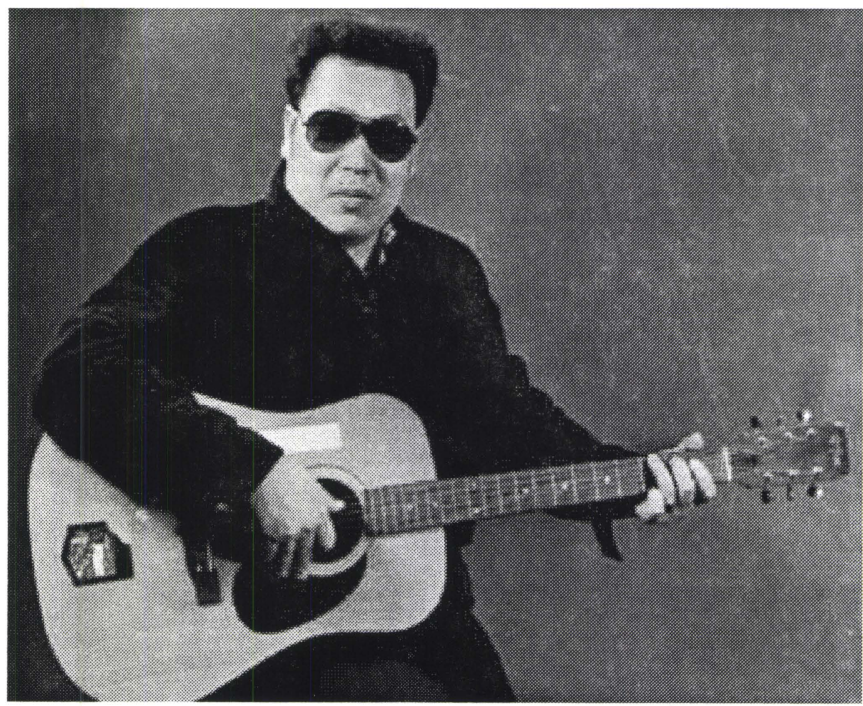

"Vaikka olen Kaukoidästä, uskon että Elvis on kansallisuuksien ja rotujen yläpuolellla. Elvistä rakastetaan joka puolella maailmaa, ja niinpä tunnen olevani oikeutettu antamaan Elvikselle minun piirteeni. Uskon että minulla on tehtävä, otan Elviksen vakavasti. Tunnen että hän ohjaa minua. Minne, sitä en tiedä, mutta minä tunnen hänen läsnäolonsa vahvana." - Elvis of Taiwan (Elvis of Taiwan, käännös kirjoittajan) 
Elviksen kopiot ovat monien mielestä yhtä kiehtovia kuin Elvis itse. Elviksen imitoinnista on kehittynyt instituutio, johon voidaan taas puolestaan viitata erilaisissa kulttuurintuotteissa. Niinpä Suomenkin elokuvateattereissa esitetyssä useiden Elvis-imitaattorien esityksiä sisältävässä 3000 Miles to Graceland -elokuvassa juonen tapahtumat sijoittuvat Elvis-konfrenssiin Las Vegasiin. Elokuvan mainosjuliste, jossa pääosan esittäjät on kuvattu Elvisasuihin sonnustautuneina, viittaa nimenomaan Elvis-imitaattoreihin, ei Elvikseen itseensä.

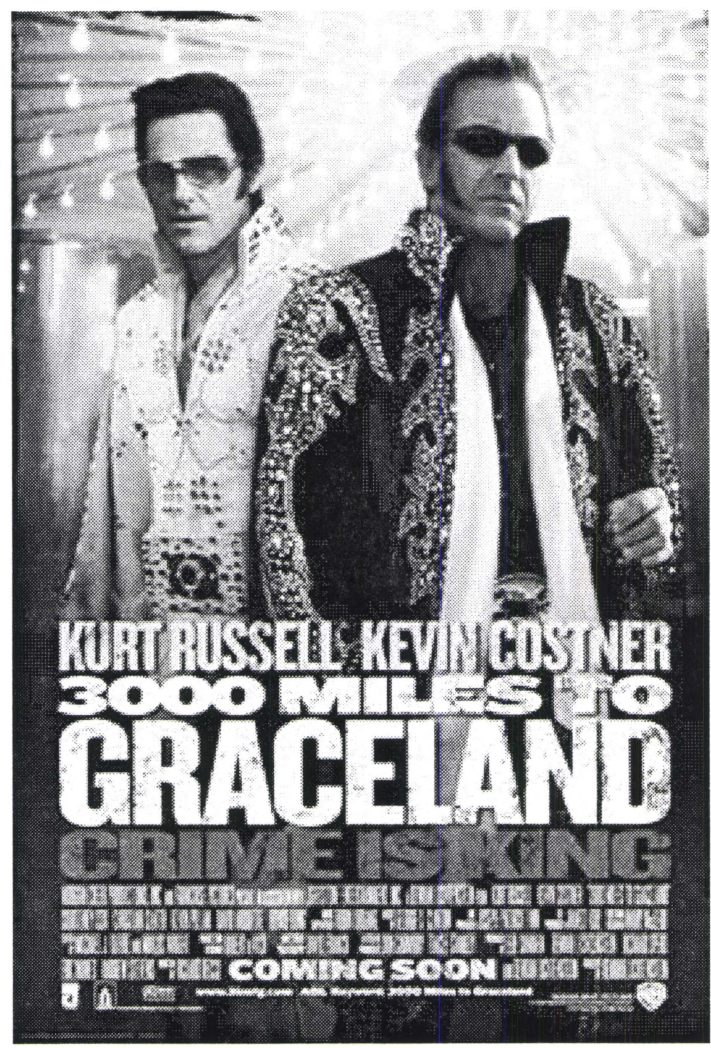

\section{Lähteet}

Aho, M. 2000. "Elämää suuremmat" - Suomi-iskelmän kuolemattomat iskelmädiskurssin antiteeseinä. Etnomusikologian vuosikirja 2000, toim. J. Niemi. Ss. 115-129.

Aho, M. 1999. Unto Mononen, Olavi Virta ja tango Suomen kansan valittuina. Etnomusikologian vuosikirja 1999, toim. J. Niemi. Ss. 91-106.

Carr, I., Fairweather, D. \& Priestley, P. 1995. Jazz. The Rough Guide. The Essential Companion to Artists and Albums. Lontoo: Penguin.

deCordova, R. 1991. The Emergence of the Star System in America. Stardom. Industry of desire, toim. C. Gledhill. Lontoo: Routledge. Ss. 9-29.

Dyer, R. 1986. Stars. London: British Film Institute.

Ellis, J. 1985. Visible Fictions. Cinema: Television: Video. Lontoo: Routledge.

Gledhill, C. 1991. Signs of Melodrama. Stardom. Industry of desire, toim. C. Gledhill. Lontoo: Routledge. Ss. $207-229$.

Grossberg, L. \& Wartella, E. \& Whitney, D. C. 1998. Media Making. Mass Media in a Popular Culture. Thousand Oaks: Sage.

Guralnick, P. 1999. Careless Love. The Unmaking of Elvis Presley. Lontoo: Abacus.

Lury, C. 1993. Cultural Rights. Technology, Legality and Personality. Lontoo: Routledge.

Mäkelä, J. 1999. Tähtisumun taakse. Reittejä populaarimusiikin tähti-ilmiön kulttuuriseen tutkimukseen. Musiikin suunta 4/1999, ss. 12-21.

Rodman, G. B. 1996. Elvis After Elvis. The Posthumous Career of a Living Legend. New York: Routledge. Shuker, R. 1998. Key Concepts in Popular Music. London: Routledge.

Thwaites, T. \& Davis, L. \& Mules, W. 1994. Tools for Cultural Studies. An Introduction. Melbourne: MacMillan. 


\section{WWW-sivut}

Elvis of Taiwan [www-dokumentti] <http://www.Elvisoftaiwan.com/index.html > (luettu 14.5.2001)

Elvis the Concert [www-dokumentti] <http://www.elvis.com/concert/>14.5.2001

Elvis.com the official website [www-dokumentti] <http://www.elvis.com/> 14.5.2001

Kim Bridges homepage [www-dokumentti] <http://www.kimbridges.co.uk/index.htm> (luettu 14.5.2001)

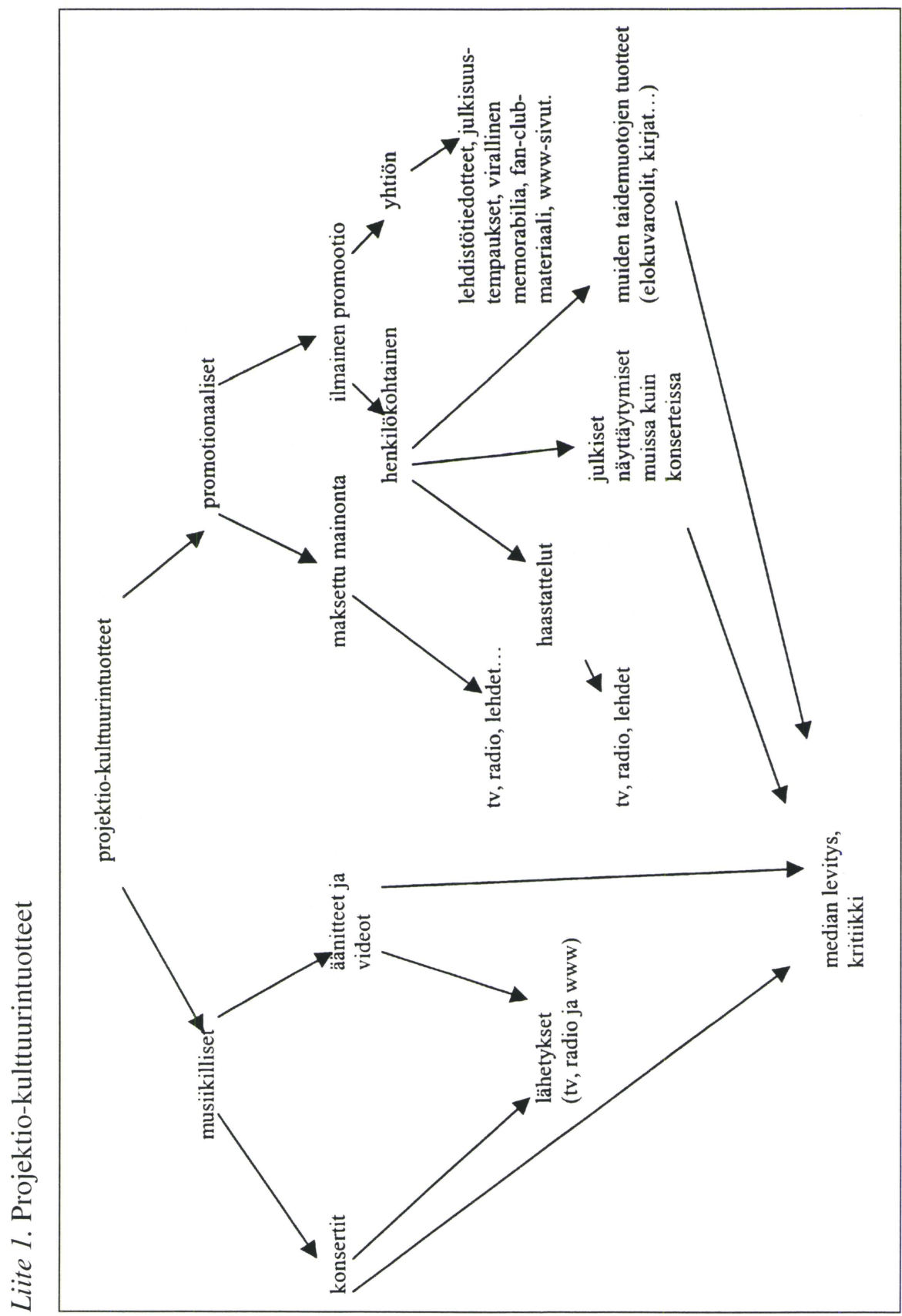




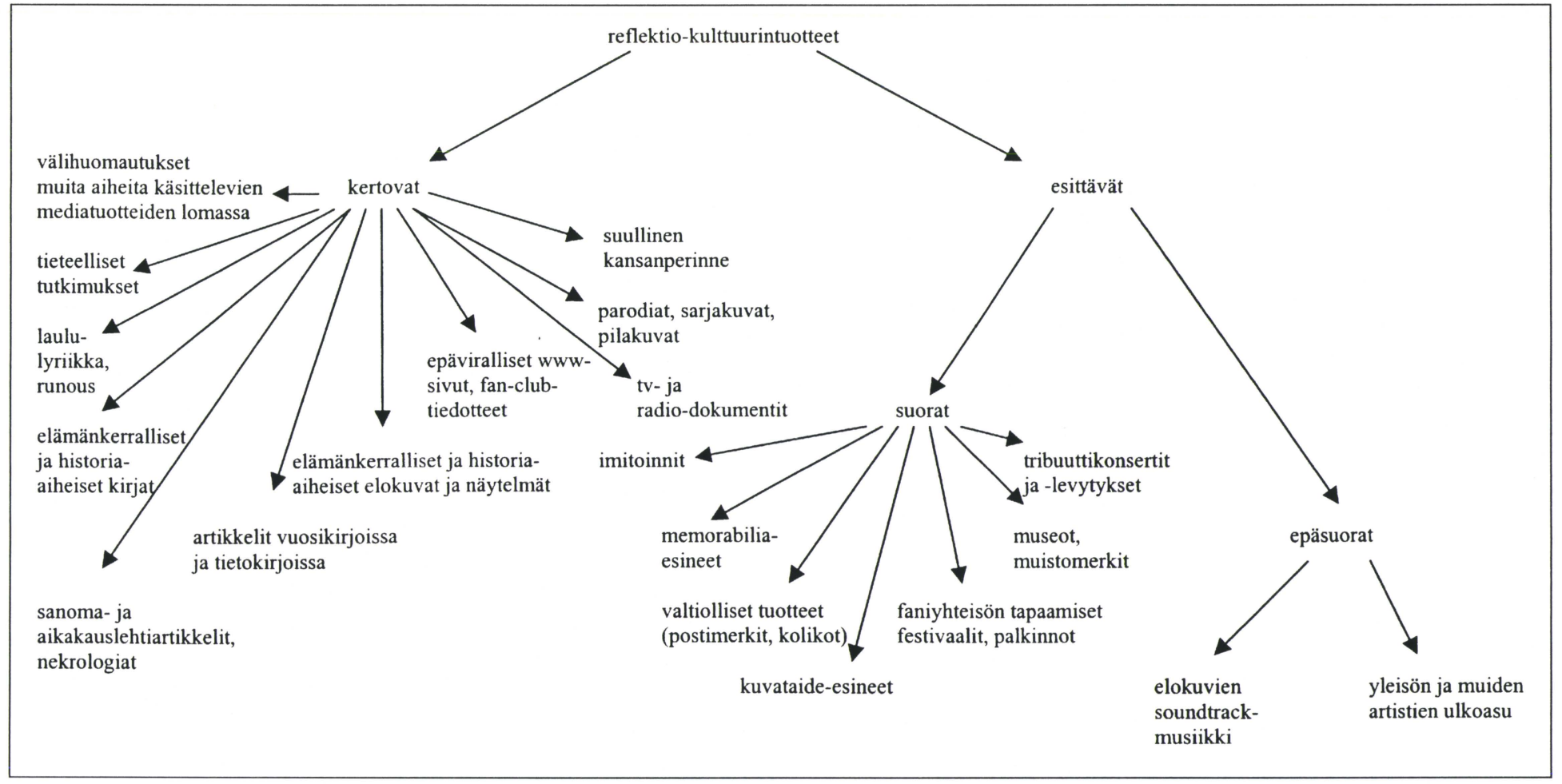

